\title{
THE EFFECTS OF POTENT ANALGESICS UPON VESTIBULAR FUNCTION
}

\author{
BY LEONARD B. GUTNER, WILBUR J. GOULD, AND ROBERT C. BATTERMAN \\ (From the Department of Therapeutics, New York University-Bellevue Medical Center, and \\ the Otorhinolaryngology Service of. Lenox Hill Hospital, New York City)
}

(Submitted for publication July 20, 1951; accepted December 27, 1951)

With the introduction of potent synthetic analgesics, it became evident upon clinical evaluation that the ambulatory patient more frequently displayed the signs and symptoms of toxicity than the bed-ridden patient. Thus, the occurrence of dizziness, nausea and vomiting was appreciably increased in the patient who was up and about and who was receiving meperidine and methadon (14). This phenomenon was not readily appreciated in the case of morphine in ambulant patients because this drug is used principally for seriously-ill bed patients and because of its decreased effectiveness when administered by the oral route. However, it had been recognized by many studying the effects of morphine in man that untoward reactions may occur more frequently in the upright position (5). Two possible approaches to the investigation of this problem were considered, the influence of such medications upon cardiovascular dynamics and their possible alterations of vestibular function. Since preliminary investigations in our laboratory failed to reveal any significant aberrations in cardiovascular dynamics with these drugs (6) this study was initiated to determine the effects of potent analgesics upon labyrinthine function.

\section{METHOD}

The methods employed were the cold micro-caloric test $(7,8)$ and galvanic stimulation of the mastoid area (9). The former consists of the injection of $2 \mathrm{cc}$. of ice water (water with floating ice) into the external auditory canal with the head inclined laterally so that the ear to be tested is uppermost. The same ear is used throughout the test. The time for the onset of nystagmus to the contralateral side is recorded with a stop-watch; and, at that point, the head is returned to the upright position, and the canal emptied of water. The duration of the true nystagmus is then noted. This test measures the sensitivity and responsiveness of the peripheral end-organ in the labyrinth and lends itself to close repetition because of its simplicity and lack of unpleasantness to the subject. The ratio of the onset to the duration of nystagmus is used as a measure of labyrinthine sensitivity for com- parative purposes, a decrease in this ratio being indicative of an increased responsiveness and an increase having the opposite implication.

The galvanic stimulation test is performed with the subject standing balanced on a tilt board holding the moistened cathode in one hand while the examiner applies the moistened anode to the contra-lateral mastoid area. The milliamperage necessary to effect tilting is noted. This method depends upon the integrity and sensitivity of the vestibular nerve tract and associated brain centers; and it, too, is devoid of complexity and rejection by the patient.

Sixteen ambulatory patients, none of whom presented any abnormalities of the ear, underwent 25 complete trials with one or more of the following drugs: codeine sulfate 60 mgms., meperidine hydrochloride 50 mgms., morphine sulfate 10 mgms., methadon 10 mgms., pantopon 20 mgms., and acetylsalicylic acid $0.6 \mathrm{gm}$. All medications with the exception of acetylsalicylic acid were given intramuscularly. In four additional subjects, six complete observations were accomplished in which dimenhydrinate 100 mgms. was ingested orally, followed 15 minutes later by the intramuscular administration of meperidine hydrochloride 50 mgms. or morphine sulfate $10 \mathrm{mgms}$. in three instances each.

The following was the procedure employed. The control period consisted of three micro-caloric determinations, at approximately five minute intervals, followed by a single base-line determination of the milliamperage required for tilting. One of the above drugs or combination of drugs was then administered. At roughly $20 \mathrm{~min}$ ute intervals one micro-caloric test and one galvanic stimulation were done, for a total of at least three such determinations or until it was felt that the maximum vestibular effects had been produced and were receding.

\section{RESULTS}

The effects of meperidine hydrochloride, morphine sulfate, methadon hydrochloride and codeine sulfate upon the onset and duration of nystagmus and their ratios are presented in Tables I-IV and Figures 1-3. For comparative purposes five representative cases from our previously reported experiences (10) with dimenhydrinate (dramamine) are included in these figures.

At this point several explanations are necessary for the better understanding of the ensuing tables. 
TABLE I

Influence of meperidine hydrochloride (50 mgms. administered intramuscularly) on vestibular function, as measured by the cold micro-caloric method

\begin{tabular}{|c|c|c|c|c|c|c|c|c|c|c|c|c|c|}
\hline \multirow{3}{*}{ Subject } & \multirow{3}{*}{$\begin{array}{c}\text { Age } \\
(y r s .)\end{array}$} & \multicolumn{4}{|c|}{$\begin{array}{l}\text { Time of onset of nystagmus } \\
\text { in seconds }\end{array}$} & \multirow{3}{*}{$\begin{array}{l}\text { Per cent } \\
\text { of } \\
\text { change }\end{array}$} & \multicolumn{4}{|c|}{ Duration of nystagmus in seconds } & \multirow{3}{*}{$\begin{array}{l}\text { Per cent } \\
\text { of } \\
\text { change }\end{array}$} & \multicolumn{2}{|c|}{$\begin{array}{l}\text { Ratio of time of onset } \\
\text { and duration of } \\
\text { nystagmus }\end{array}$} \\
\hline & & \multirow{2}{*}{ Control* } & \multicolumn{3}{|c|}{ Meperidine } & & \multirow{2}{*}{ Control* } & \multicolumn{3}{|c|}{ Meperidine } & & \multirow{2}{*}{ Control } & \multirow{2}{*}{ Meperidinet } \\
\hline & & & 1 & 2 & 3 & & & 1 & 2 & 3 & & & \\
\hline $\begin{array}{l}\text { L. B. } \\
\text { M. M. } \\
\text { A.t. } \\
\text { W. } \\
\text { M. } \\
\text { K. }\end{array}$ & $\begin{array}{l}55 \\
47 \\
77 \\
45 \\
39\end{array}$ & $\begin{array}{l}27(30,31,21) \\
22^{-}(23,22,21) \\
25(27,26,23) \\
31(27,33,34) \\
25(24,22,28)\end{array}$ & $\begin{array}{l}29 \\
22 \\
26 \\
39 \\
23\end{array}$ & $\begin{array}{l}32 \\
20 \\
22 \\
26 \\
21\end{array}$ & $\begin{array}{l}\overline{22} \\
20 \\
25 \\
28\end{array}$ & $\begin{array}{r}0 \\
0 \\
-20 \\
+24 \\
0\end{array}$ & $\begin{array}{l}90(98,90,81) \\
93(92,89,98) \\
84(89,84,79) \\
88(83,88,93) \\
96(90,99,99)\end{array}$ & $\begin{array}{r}129 \\
143 \\
129 \\
98 \\
134\end{array}$ & $\begin{array}{r}107 \\
80 \\
131 \\
128 \\
149\end{array}$ & $\begin{array}{r}- \\
86 \\
108 \\
87 \\
102\end{array}$ & $\begin{array}{l}+43 \\
+54 \\
+56 \\
+45 \\
+55\end{array}$ & $\begin{array}{l}1: 3.3 \\
1: 4.2 \\
1: 3.4 \\
1: 2.8 \\
1: 3.8\end{array}$ & $\begin{array}{l}1: 4.4 \\
1: 6.5 \\
1: 6.0 \\
1: 5.0 \\
1: 7.1\end{array}$ \\
\hline
\end{tabular}

* Average of three determinations.

$\dagger$ Maximal effect of drug.

Note: Boldface numbers are components of ratios in last column on right.

TABLE II

Influence of morphine sulfate (10 mgms. administered intramuscularly) on vestibular function, as measured by the cold micro-caloric method

\begin{tabular}{|c|c|c|c|c|c|c|c|c|c|c|c|c|c|}
\hline \multirow{3}{*}{ Subject } & \multirow{3}{*}{$\begin{array}{c}\text { Age } \\
\text { (yrs.) }\end{array}$} & \multicolumn{4}{|c|}{$\begin{array}{l}\text { Time of onset of nystagmus } \\
\text { in seconds }\end{array}$} & \multirow{3}{*}{$\begin{array}{l}\text { Per cent } \\
\text { of } \\
\text { change }\end{array}$} & \multicolumn{4}{|c|}{ Duration of nystagmus in seconds } & \multirow{3}{*}{$\begin{array}{l}\text { Per cent } \\
\text { of } \\
\text { change }\end{array}$} & \multicolumn{2}{|c|}{$\begin{array}{l}\text { Ratio of time of } \\
\text { onset and duration } \\
\text { of nystagmus }\end{array}$} \\
\hline & & \multirow{2}{*}{ Control* } & \multicolumn{3}{|c|}{ Morphine sulfate } & & \multirow{2}{*}{ Control* } & \multicolumn{3}{|c|}{ Morphine sulfate } & & \multirow{2}{*}{ Control } & \multirow{2}{*}{$\begin{array}{c}\text { Morphine } \\
\text { sulfatef }\end{array}$} \\
\hline & & & 1 & 2 & 3 & & & 1 & 2 & 3 & & & \\
\hline $\begin{array}{l}\text { M. K. } \\
\text { M. N. } \\
\text { F. W. } \\
\text { L. B. }\end{array}$ & $\begin{array}{l}39 \\
58 \\
48 \\
55\end{array}$ & $\begin{array}{l}24(23,22,27) \\
29(28,27,31) \\
28(24,33,26) \\
27(27,26,27)\end{array}$ & $\begin{array}{l}22 \\
32 \\
19 \\
36\end{array}$ & $\begin{array}{l}24 \\
20 \\
18 \\
22\end{array}$ & $\begin{array}{l}25 \\
22 \\
28 \\
26\end{array}$ & $\begin{array}{r}0 \\
-31 \\
-36 \\
+33 \\
-18\end{array}$ & $\begin{aligned} 111 & (111,110,112) \\
85 & (82,90,84) \\
113 & (107,121,110) \\
88 & (96,74,95)\end{aligned}$ & $\begin{array}{l}115 \\
106 \\
131 \\
115\end{array}$ & $\begin{array}{l}147 \\
120 \\
130 \\
114\end{array}$ & $\begin{array}{r}114 \\
91 \\
120 \\
82\end{array}$ & $\begin{array}{l}+32 \\
+41 \\
+16 \\
+31\end{array}$ & $\begin{array}{l}1: 4.6 \\
1: 3.0 \\
1: 4.0 \\
1: 3.3\end{array}$ & $\begin{array}{l}1: 6.1 \\
1: 6.0 \\
1: 7.2 \\
1: 5.2\end{array}$ \\
\hline M. S. & 60 & $22(20,22,23)$ & 18 & 18 & 20 & -18 & $90(87,90,92)$ & 110 & 130 & 118 & +44 & $1: 4.1$ & $1: 7.2$ \\
\hline
\end{tabular}

* Average of three determinations.

$\dagger$ Maximal effect of drug.

Note: Boldface numbers are components of ratios in last column on right.

TABLE III

Influence of methadon (10 mgms. administered intramuscularly) on vestibular function, as measured by. the cold micro-caloric method

\begin{tabular}{|c|c|c|c|c|c|c|c|c|c|c|c|c|c|}
\hline \multirow{3}{*}{ Subject } & \multirow{3}{*}{$\begin{array}{c}\text { Age } \\
(y r s .)\end{array}$} & \multicolumn{4}{|c|}{$\begin{array}{l}\text { Time of onset of nystagmus } \\
\text { in seconds }\end{array}$} & \multirow{3}{*}{$\begin{array}{l}\text { Per cent } \\
\text { of } \\
\text { change }\end{array}$} & \multicolumn{4}{|c|}{ Duration of nystagmus in seconds } & \multirow{3}{*}{$\begin{array}{c}\text { Per cent } \\
\text { of } \\
\text { change }\end{array}$} & \multicolumn{2}{|c|}{$\begin{array}{l}\text { Ratio of time of } \\
\text { onset and duration } \\
\text { of nystagmus }\end{array}$} \\
\hline & & \multirow{2}{*}{ Control* } & \multicolumn{3}{|c|}{ Methadon } & & \multirow{2}{*}{ Control* } & \multicolumn{3}{|c|}{ Methadon } & & & \\
\hline & & & 1 & 2 & 3 & & & 1 & 2 & 3 & & & \\
\hline $\begin{array}{l}\text { A. P. } \\
\text { L. K. } \\
\text { M. A. } \\
\text { M. N. } \\
\text { M. K. }\end{array}$ & $\begin{array}{l}22 \\
25 \\
21 \\
58 \\
39\end{array}$ & $\begin{array}{l}31(32,30,32) \\
26(25,28,26) \\
27(30,25,25) \\
24(26,22,25) \\
24(24,29,18)\end{array}$ & $\begin{array}{l}28 \\
23 \\
17 \\
21 \\
24\end{array}$ & $\begin{array}{l}28 \\
24 \\
19 \\
17 \\
24\end{array}$ & $\begin{array}{l}30 \\
26 \\
17 \\
16 \\
21\end{array}$ & $\begin{array}{r}-10 \\
-11 \\
-37 \\
-33 \\
0\end{array}$ & $\begin{aligned} 102 & (102,98,106) \\
97 & (98,94,100) \\
103 & (113,97,98) \\
92 & (96,90,91) \\
102 & (103,100,102)\end{aligned}$ & $\begin{array}{l}115 \\
110 \\
133 \\
122 \\
129\end{array}$ & $\begin{array}{l}120 \\
133 \\
118 \\
116 \\
118\end{array}$ & \begin{tabular}{|r|}
115 \\
108 \\
123 \\
92 \\
105
\end{tabular} & $\begin{array}{l}+18 \\
+37 \\
+29 \\
+33 \\
+26\end{array}$ & $\begin{array}{l}1: 3.3 \\
1: 3.7 \\
1: 3.8 \\
1: 3.8 \\
1: 4.2\end{array}$ & $\begin{array}{l}1: 4.3 \\
1: 5.5 \\
1: 7.8 \\
1: 6.8 \\
1: 5.4\end{array}$ \\
\hline
\end{tabular}

* Average of three determinations.

$t$ Maximal effect of drug.

Note: Boldface numbers are components of ratios in last column on right. 
TABLE IV

Influence of codeine sulfate (60 mgms. administered intramuscularly) on vestibular function, as measured by the cold micro-caloric method

\begin{tabular}{|c|c|c|c|c|c|c|c|c|c|c|c|c|c|}
\hline \multirow{3}{*}{ Subject } & \multirow{3}{*}{$\begin{array}{l}\text { Age } \\
\text { (yrs.) }\end{array}$} & \multicolumn{4}{|c|}{$\begin{array}{l}\text { Time of onset of nystagmus } \\
\text { in seconds }\end{array}$} & \multirow{3}{*}{$\begin{array}{l}\text { Per cent } \\
\text { of } \\
\text { change }\end{array}$} & \multicolumn{4}{|c|}{ Duration of nystagmus in seconds } & \multirow{3}{*}{$\begin{array}{l}\text { Per cent } \\
\text { of } \\
\text { change }\end{array}$} & \multicolumn{2}{|c|}{$\begin{array}{l}\text { Ratio of time of } \\
\text { onset and duration } \\
\text { of nystagmus }\end{array}$} \\
\hline & & \multirow{2}{*}{ Control* } & \multicolumn{3}{|c|}{ Codeine } & & \multirow{2}{*}{ Control* } & \multicolumn{3}{|c|}{ Codeine } & & \multirow{2}{*}{ Control } & \multirow{2}{*}{ Codeinet } \\
\hline & & & 1 & 2 & 3 & & & 1 & 2 & 3 & & & \\
\hline M. K. & 39 & $25(25,25,25)$ & 22 & 22 & 28 & -12 & $106(112,100,105)$ & 77 & 58 & 89 & -45 & $1: 4.2$ & $1: 2.6$ \\
\hline $\begin{array}{l}\text { M. V. } \\
\text { M. K. } \\
\text { W. M. } \\
\text { M. M. } \\
\text { L. B. }\end{array}$ & $\begin{array}{l}65 \\
78 \\
45 \\
47 \\
55\end{array}$ & $\begin{array}{l}30(34,25,30) \\
24(24,24,25) \\
25(21,27,26) \\
25(29,24,23) \\
28(27,28,30)\end{array}$ & $\begin{array}{l}35 \\
25 \\
24 \\
24 \\
21\end{array}$ & $\begin{array}{l}30 \\
24 \\
26 \\
22 \\
27\end{array}$ & $\begin{array}{l}32 \\
27 \\
26 \\
22 \\
26\end{array}$ & $\begin{array}{r}0 \\
+12 \\
0 \\
0 \\
-25\end{array}$ & $\begin{aligned} & 113(123,101,114) \\
& 123(128,125,116) \\
& 97(103,90,98) \\
& 98(97,98,99) \\
& 99(101,101,94)\end{aligned}$ & $\begin{array}{r}70 \\
113 \\
77 \\
76 \\
86\end{array}$ & $\begin{array}{r}103 \\
115 \\
97 \\
85 \\
60\end{array}$ & $\begin{array}{r}104 \\
127 \\
96 \\
99 \\
76\end{array}$ & $\begin{array}{r}-38 \\
-8 \\
-21 \\
-22 \\
-40\end{array}$ & $\begin{array}{l}1: 3.8 \\
1: 5.1 \\
1: 3.9 \\
1: 3.9 \\
1: 3.5\end{array}$ & $\begin{array}{l}1: 2 \\
1: 4.5 \\
1: 3.2 \\
1: 3.1 \\
1: 2.2\end{array}$ \\
\hline
\end{tabular}

* Average of three determinations.

$\dagger$ Maximal effect of drug.

Note: Boldface numbers are components of ratios in last column on right.

All the original control data for the onsets and durations of nystagmus and their averages are recorded. The testing periods after the administration of the various drugs are designated by the numbers 1,2 , and 3 and represent approximately 20 minute intervals. The percentages of change are derived by comparing the maximal effect of a drug with the average control figure. Arbitrarily, any resultant quantity falling within the range of the control values or differing by only one second has been recorded as unchanged. The control ratios are calculated from the average control values. The ratios following drug administration are computed from quantities for the onsets and durations which reflect the maximal effects of these drugs (in boldface for easier interpretation) and which must of necessity have occurred during the same test interval.

Meperidine, morphine and methadon produced an increase in labyrinthine responsiveness. The

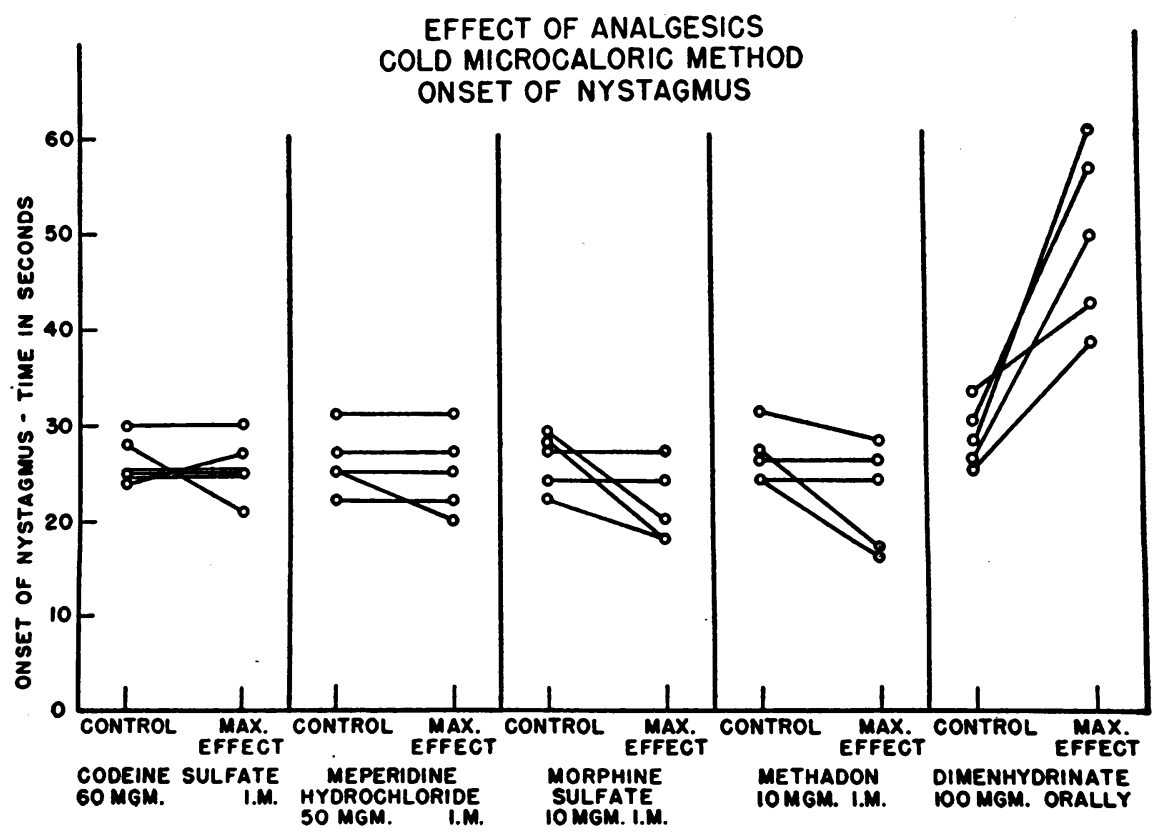

Fig. 1 


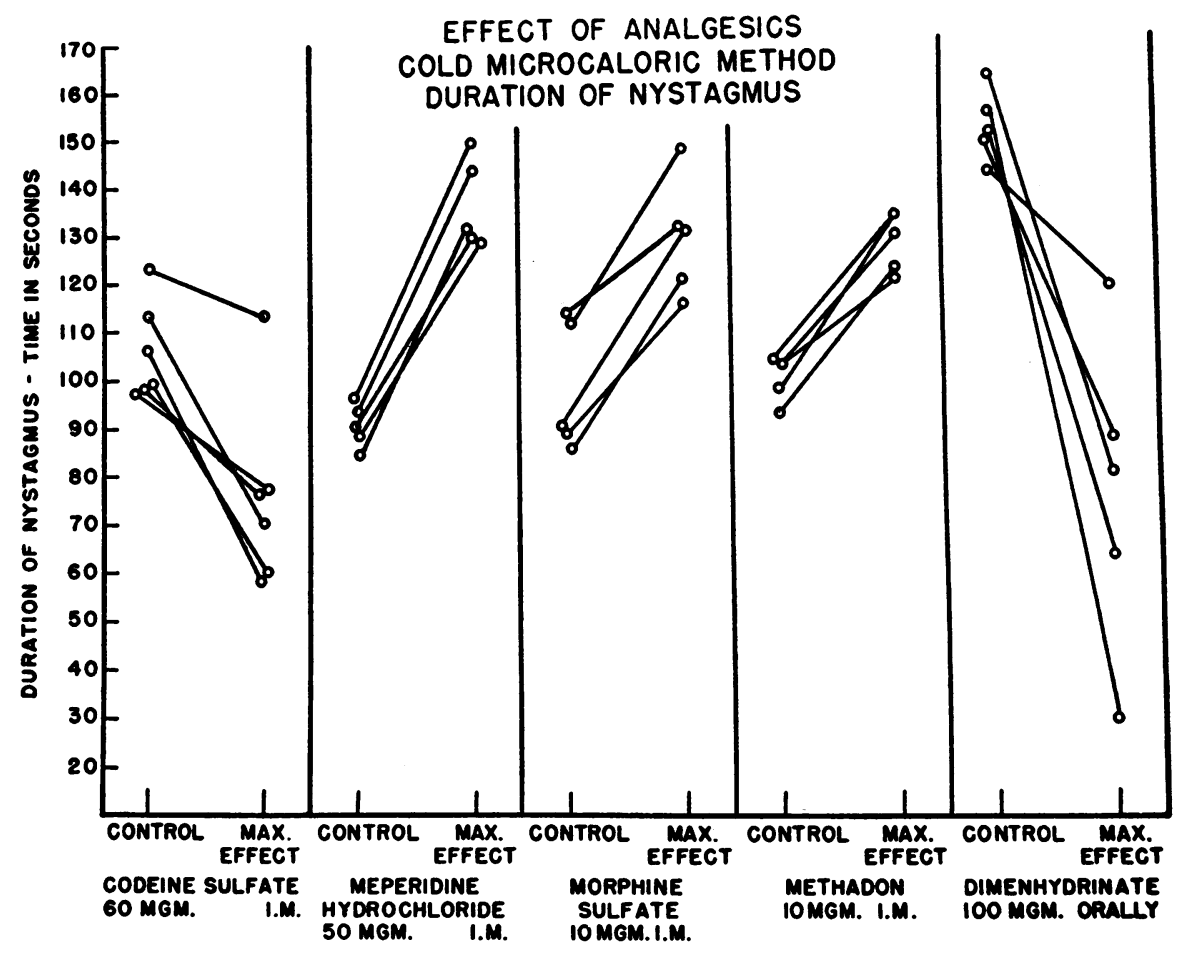

FIG. 2

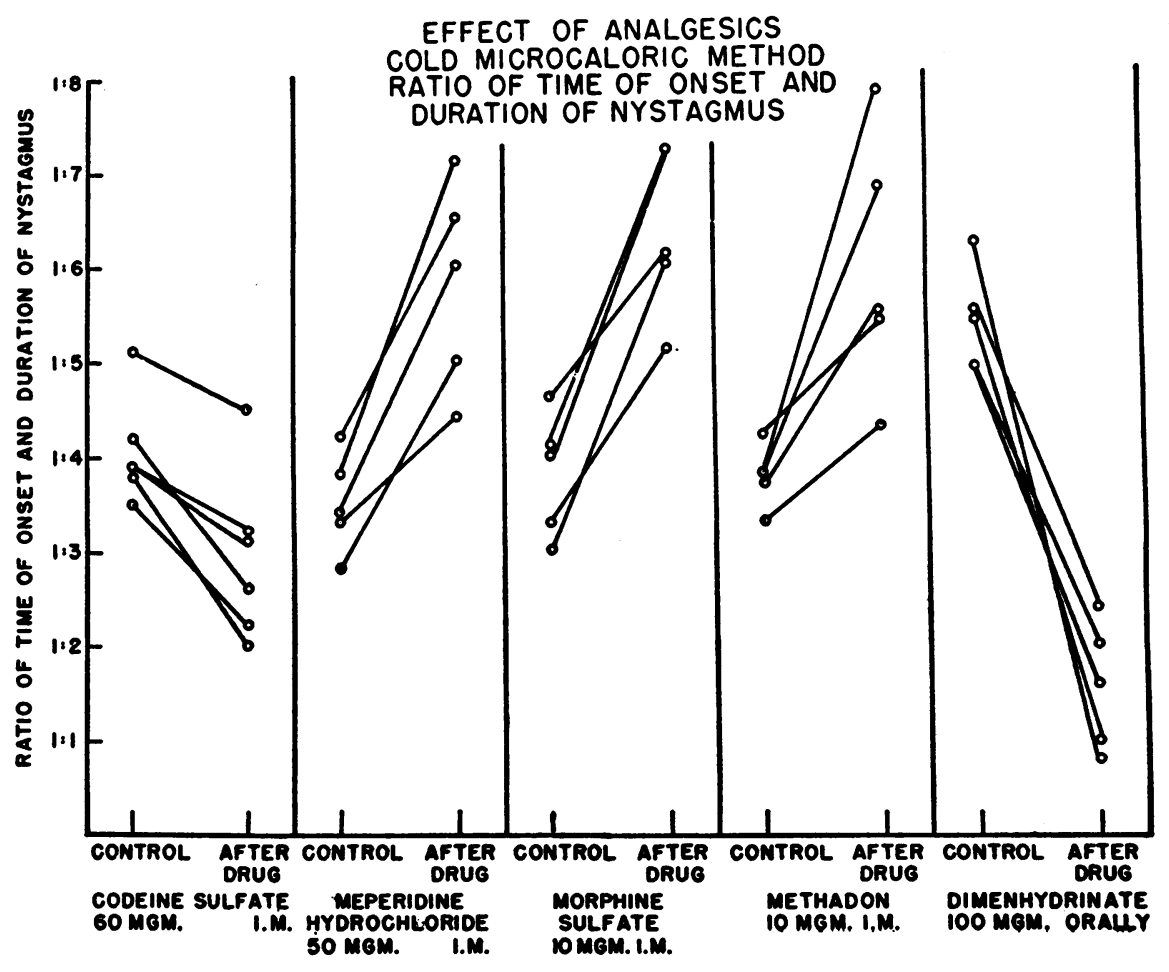

Fig. 3 


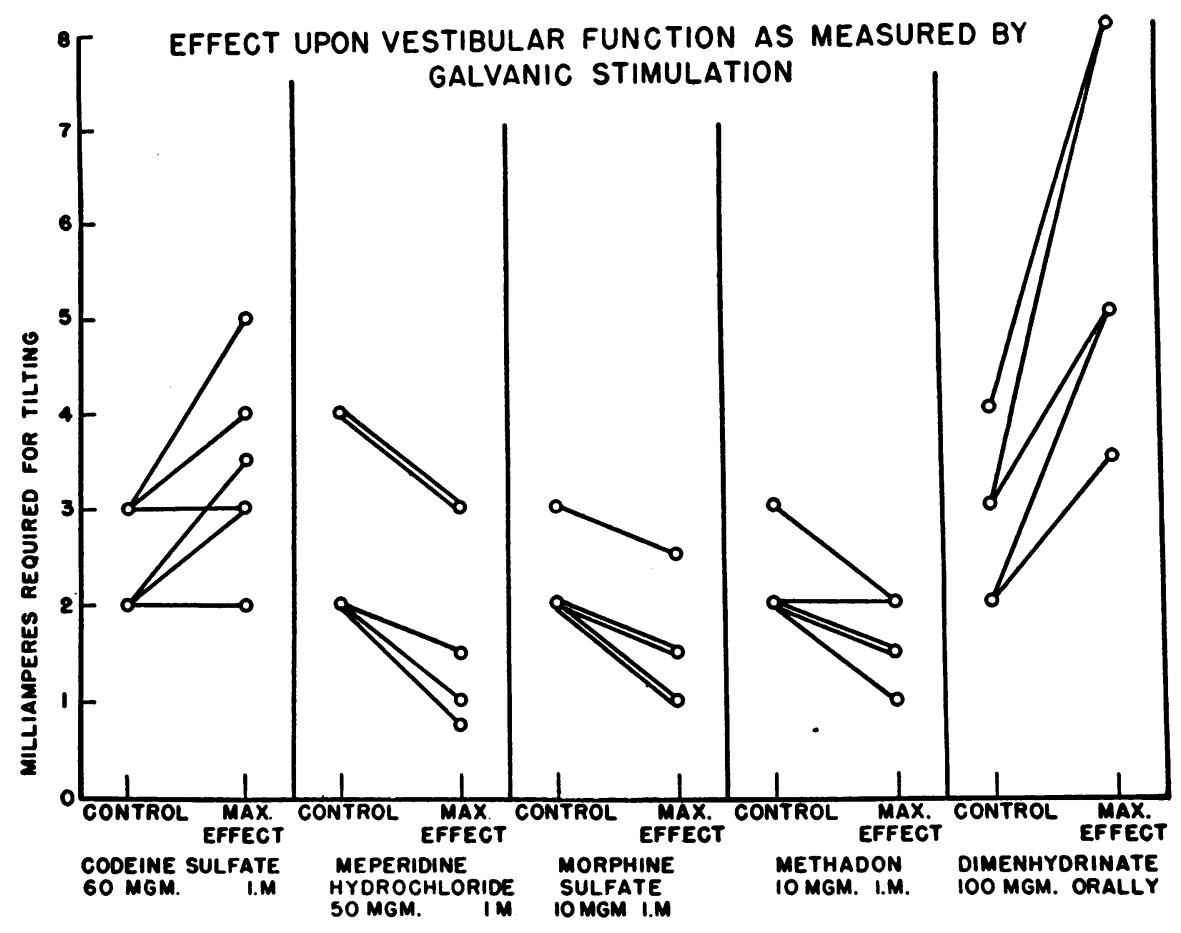

FIG. 4

onset of nystagmus was unaffected with meperidine, but both morphine and methadon decreased the onset of nystagmus in three out of five instances. In the five trials with each of these drugs, the duration of nystagmus was prolonged in every trial. The ratio of onset to duration was also decreased in every case.

The effects of these drugs upon vestibular function as measured by galvanic stimulation are presented in Figure 4. Again dimenhydrinate is included for comparison. With this method the amount of current necessary to effect tilting was decreased in every patient with these medications, except for one trial with methadon.

Codeine was the only drug of those included in this study which decreased the reactivity of the labyrinth. The onset of nystagmus was unchanged; however, the duration was decreased in every instance and the resultant ratio was materially raised in each of the six trials. Four of the six patients when tested galvanically exhibited an increase in the milliamperage needed to produce tilting.

Two patients were studied with pantopon and

TABLE V

Influence of pantopon (20 mgms. administered intramuscularly) on vestibular function, as measured by the cold micro-caloric method

\begin{tabular}{|c|c|c|c|c|c|c|c|c|c|c|c|c|c|}
\hline \multirow{3}{*}{ Subject } & \multirow{3}{*}{$\begin{array}{c}\text { Age } \\
(y r s .)\end{array}$} & \multicolumn{4}{|c|}{$\begin{array}{l}\text { Time of onset of nystagmus } \\
\text { in seconds }\end{array}$} & \multirow{3}{*}{$\begin{array}{l}\text { Per cent } \\
\text { of } \\
\text { change }\end{array}$} & \multicolumn{4}{|c|}{ Duration of nystagmus in seconds } & \multirow{3}{*}{$\begin{array}{l}\text { Per cent } \\
\text { of } \\
\text { change }\end{array}$} & \multicolumn{2}{|c|}{$\begin{array}{l}\text { Ratio of time of } \\
\text { onset and duration } \\
\text { of nystagmus }\end{array}$} \\
\hline & & \multirow{2}{*}{ Control* } & \multicolumn{3}{|c|}{ Pantopon } & & \multirow{2}{*}{ Control* } & \multicolumn{3}{|c|}{ Pantopon } & & & \\
\hline & & & 1 & 2 & 3 & & & 1 & 2 & 3 & & & \\
\hline $\begin{array}{l}\text { M. M. } \\
\text { M. G. }\end{array}$ & $\begin{array}{l}57 \\
48\end{array}$ & $\begin{array}{l}23(24,20,24) \\
19(20,19,18)\end{array}$ & $\begin{array}{l}20 \\
14\end{array}$ & $\begin{array}{l}18 \\
18\end{array}$ & $\begin{array}{l}19 \\
18\end{array}$ & $\begin{array}{l}-9 \\
-26\end{array}$ & $\begin{aligned} 91 & (91,88,95) \\
102 & (97,105,105)\end{aligned}$ & $\begin{array}{l}125 \\
130\end{array}$ & $\begin{array}{l}130 \\
124\end{array}$ & $\begin{array}{r}88 \\
107\end{array}$ & $\begin{array}{l}+43 \\
+27\end{array}$ & $\begin{array}{l}1: 4.0 \\
1: 5.4\end{array}$ & $\begin{array}{l}1: 7.2 \\
1: 9.3\end{array}$ \\
\hline
\end{tabular}

* Average of three determinations.

$\dagger$ Maximal effect of drug.

Note: Boldface numbers are components of ratios in last column on right. 


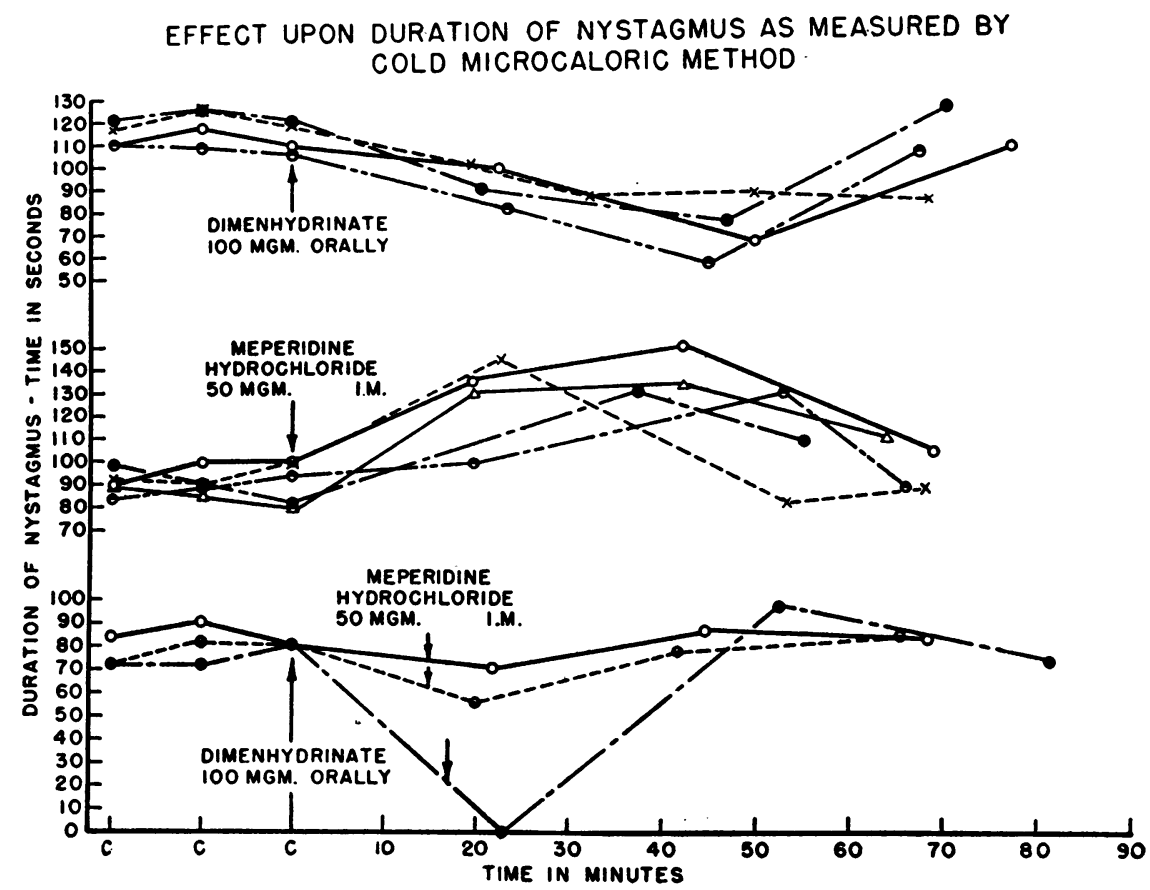

FIG. 5

the results were similar to morphine sulfate (Table V). Acetylsalicylic acid was administered orally in a dose of $0.6 \mathrm{gm}$. and had no effect upon vestibular function as measured by these methods.

Having thus established that meperidine, morphine and methadon stimulate the labyrinthine mechanism, it was felt from our previous studies on the pharmacology of dimenhydrinate that the use of this medication prior to the administration of these potent analgesics would offset their action upon the balance mechanism (10). This was borne out in two subjects in whom the vestibular effects of intramuscular meperidine were completely blocked by the use of $100 \mathrm{mgms}$. of dimenhydrinate orally. The third individual exhibited a partial inhibition of meperidine action. This is presented in Figure 5. The comparative effects of dimenhydrinate and meperidine hydrochloride when administered alone are shown in four and five subjects, respectively. The same results were observed in three trials with dimenhydrinate and morphine sulfate.

In addition to the above studies, the action of meperidine $50 \mathrm{mgms}$. intramuscularly was observed in three subjects in both the supine and upright positions on successive days with the aid of the cold micro-caloric method alone (Table VI).
In all three cases the prolongation of the induced nystagmus was greater when the patient was ambulant than when he was lying in bed throughout the observation period. Because of this observation, the resultant ratios tended to reflect an overall increase in labyrinthine sensitivity in the upright position in spite of the fact that two patients in this position exhibited a prolongaton in the onset of nystagmus, a fact which ordinarily would tend to decrease the vestibular responsiveness. This again is in agreement with our previous clinical evaluation of these drugs, and probably results from the greater stress placed upon the balance mechanism in the upright position.

\section{DISCUSSION}

The effects of the potent analgesic drugs such as meperidine, morphine and methadon upon vestibular function indicate that the higher incidence of untoward reactions noted when these therapeutic agents are used in ambulatory patients may possibly be due to the resultant increased sensitivity of the labyrinthine apparatus. However, we feel that this is not the entire explanation since the administration of codeine which apparently depresses vestibular function, still is attended by this same increased frequency of untoward reactions 


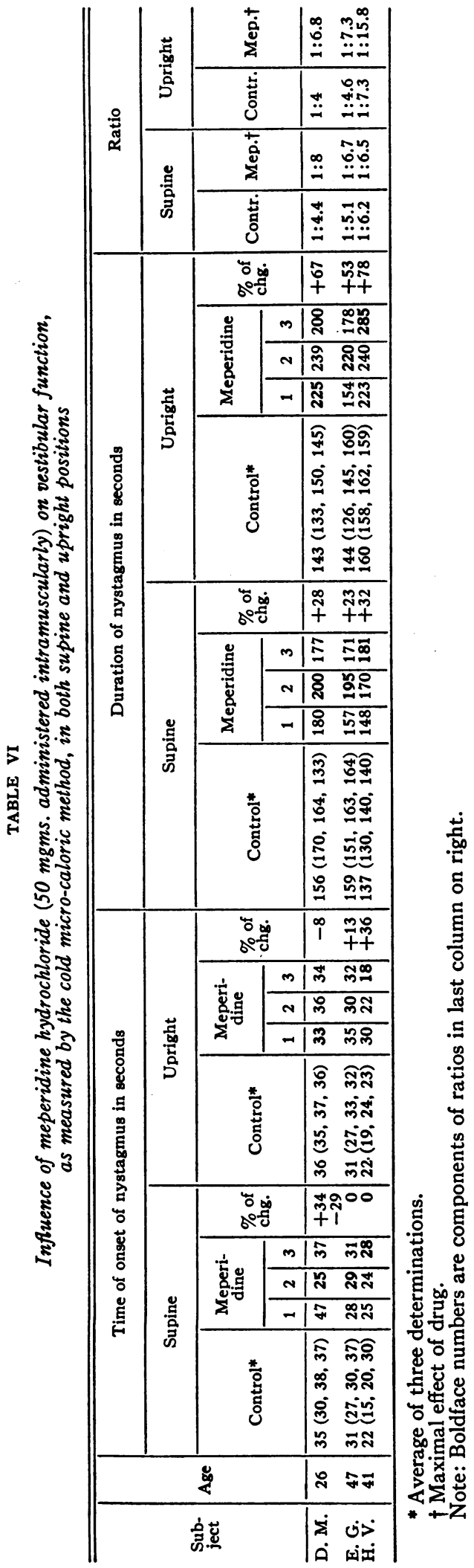

in ambulant patients. Other factors may also contribute to this phenomenon, such as stimulation of the cerebral emetic center, alterations in cerebral blood flow, and changes in cardiovascular dynamics not accurately measurable with available techniques.

Ross, Fish and Olsen in 1931 studied the effects of morphine in dogs by a rotational method, but were unable to demonstrate any increase in the duration of the induced nystagmus (11). In 1950 Rubin and Winston evaluated vestibular responses in man following morphine administration by means of the Barany chair and a macro-caloric method (12). They concluded that "morphine administration produced a significant decrease in vestibular response," yet they also concluded that the nauseant and emetic effects of morphine were markedly enhanced by vestibular stimulation. These conclusions appear to us to be mutually contradictory. Their findings of a decrease in vertigo and duration of postrotational nystagmus after morphine justify their conclusion of vestibular depression, but our studies with the cold microcaloric and galvanic methods lead us to the opposite conclusion of vestibular stimulation. They also were unable to demonstrate the decreased labyrinthine sensitivity produced by dimenhydrinate, but they did note that the drug was capable of clinically decreasing the untoward symptoms resulting from morphine usage.

\section{SUMMARY}

1. Vestibular responses to morphine, meperidine, codeine, methadon, pantopon and acetylsalicylic acid were studied in man by means of the cold micro-caloric and galvanic stimulation methods.

2. Morphine, meperidine, methadon, and pantopon increased labyrinthine sensitivity while codeine exerted an opposite action. Acetylsalicylic acid produced no changes in vestibular function.

3. Meperidine produced an increased reaction in the cold micro-caloric test in both supine and ambulant patients, but the response in the latter was of greater magnitude.

4. This resultant increased labyrinthine sensitivity may be partially responsible for the higher frequency of dizziness, nausea and vomiting encountered in ambulant patients. 
5. Dimenhydrinate is capable of overcoming this resultant increased vestibular response.

\section{REFERENCES}

1. Batterman, R. C., Clinical effectiveness and safety of a new synthetic analgesic drug, demerol. Arch. Int. Med., 1943, 71, 345.

2. Batterman, R. C., Demerol : a new synthetic analgesic; its indications as a substitute for morphine. Connecticut M. J., 1944, 8, 13.

3. Batterman, R. C., The clinical aspects of evaluating analgesic agents, with notes on the safety of morphine. Yale J. Biol. \& Med., 1946, 18, 595.

4. Batterman, R. C., and Oshlag, A. M., The effectiveness and toxicity of Methadon, a new analgesic agent. Anesthesiology, 1949, 10, 214.

5. Comroe, J. H., Jr., and Dripps, R. D., Reactions to morphine in ambulatory and bed patients. Surg., Gynec. \& Obst., 1948, 87, 221.

6. Unpublished observations.
7. Atkinson, M., A simple quantitative method of testing vestibular function. Arch. Otolaryng., 1939, 30, 916.

8. McNally, W. J., The physiology of the vestibular mechanism in relation to vertigo. Ann. Otol., Rhin. \& Laryng., 1947, 56, 514.

9. Fowler, E. P., Medicine of the ear, in Nelson LooseLeaf Medicine of the Ear. Thomas Nelson \& Sons, New York, 1948, 2nd edition, p. 439.

10. Gutner, L. B., Gould, W. J., and Batterman, R. C., Action of dimenhydrinate (dramamine) and other drugs on vestibular function. Arch. Otolaryng., 1951, 53, 308.

11. Ross, E. L., Fish, M. W., and Olsen, A., Effects of some drugs on the vestibular response to rotation. Arch. of Otolaryng., 1931, 14, 755.

12. Rubin, A., and Winston, J., The role of the vestibular apparatus in the production of nausea and vomiting following the administration of morphine to man. Clinical and experimental data including the effects of dramamine and benzedrine. J. Clin. Invest., 1950, 29, 1261.

\section{ANNOUNCEMENT OF MEETINGS}

The 44th annual meeting of the American Society for Clinical Investigation will be held at the Chalfonte-Haddon Hall, Atlantic City, N. J., on Monday, May 5, 1952, at 9 a.m.

Also at the Chalfonte-Haddon Hall on Tuesday, May 6, and the morning of Wednesday, May 7, 1952, will be the meeting of the Association of American Physicians. 